The Canadian Journal of Higher Education

La revue canadienne d'enseignement supérieur

Volume XXX, No. 2, 2000 pages $57-86$

\title{
Resource Allocation and Public Policy in Alberta's Postsecondary System
}

\section{BOB BARNETSON \& ALICE BOBERG}

Alberta Colleges and Institutes Faculties Association \& The University of Calgary

\section{ABSTRACT}

Resource allocation in Alberta's postsecondary system has changed substantially since 1994 . The changes evident are designed to advance a policy agenda that includes reapportioning financial responsibility for higher education, increasing the vocational outcomes of postsecondary education and increasing the transfer of knowledge and technology to the private sector. This paper outlines how resource allocation has been restructured to advance this agenda and points to some implications of this approach.

\section{RÉSUMÉ}

Depuis 1994 , la politique de financement des institutions d'enseignement au niveau postsecondaire en Alberta a été grandement modifiée. Ces modifications permettent d'établir, en priorité, un échéancier clair sur une nouvelle redistribution des allocations des ressources, particulièrement au soutien à l'enseignement supérieur, à l'accroissement de l'accessibilité des finissants au marché du travail et à l'augmentation du transfert des connaissances et de la technologie vers le secteur privé. Cet ouvrage souligne particulièrement comment les modifications à la politique de financement servent l'agenda prévu et certaines des conséquences de son application. 
This paper outlines how government policy objectives have shaped resource allocation in Alberta's public postsecondary system in the 1990s. The 1994 changes in postsecondary funding were designed to achieve the following three policy objectives:

1. Financial responsibility for higher education needs to be reapportioned. The Government of Alberta is decreasing public funding; the consequent pressure on postsecondary institutions to increase funding derived from both students and the private sector is designed to reapportion financial responsibility for higher education. Changes to the source of postsecondary funding advances the government's other policy objectives.

2. Higher education should provide labour market training. Government policy documents clearly frame higher education as a source of vocational training and they direct institutions to be increasingly responsive to the needs of the market. The government minimizes the political cost of imposing this agenda by restructuring resource allocation to advance this agenda. This restructuring makes institutions more dependent upon (ergo more responsive to) the demands of students and corporations. This increasing responsiveness to the market is reinforced by government's use of funding envelopes.

3. Higher education should develop and transfer knowledge and technology to the private sector. Government policy documents clearly indicate that higher education should increase the commercialization of research. Again, the government is inducing this outcome by restructuring resource allocation. In this way it avoids conflict over the consequent erosion of institutional autonomy.

The extent to which resource allocation is used to achieve government policy objectives suggests that government is unlikely to substantially alter its approach to funding unless its goals change. This paper first explores Alberta's higher education policy objectives and how the province allocates funding in the postsecondary system. Subsequently, 
the way in which resource allocation is used to achieve these objectives is discussed. Finally, some of the implications of government policy are outlined.

\section{HIGHER EDUCATION POLICY IN THE 1990s}

In 1994, the Government of Alberta issued a White Paper detailing the future direction of postsecondary education (AECD, 1994a). This document, entitled New direction for adult learning in Alberta, codified three policy objectives that had been evident in government documents for some time:

1. the reapportionment of responsibility for funding higher education;

2. the expectation that postsecondary institutions would become increasingly responsive to labour market training demands; and

3. the expectation that postsecondary institutions would increase the transfer of knowledge and technology to the private sector.

This section initially details government expectations that declining public funding are to be offset by increased revenues from students and the private sector. Subsequently, government statements about increasing institutional responsiveness to the needs of the labour market are explored. Finally, government expectations that postsecondary institutions will develop and transfer knowledge and technology to the private sector are outlined.

\section{Reapportioning financial responsibility for higher education}

As part of the province's deficit and debt elimination strategies, government spending on higher education funding was reduced by $21 \%$ over three years beginning in 1994 (AECD, 1994a). This reduction was consistent with a long-term trend that saw real-dollar, per-student grants decline by $45.8 \%$ between 1982 and 1997 (See Table 1). Discussion papers and policy documents indicate that declining public funding will be offset by increased corporate involvement and higher tuition. This expectation is most clearly outlined in the 1997 provincial human 
Table 1

Real-dollar, per-student government grants, 1982 to 1997.

\begin{tabular}{lcccc}
\hline Year & $\begin{array}{c}\text { Operations } \\
\text { Grant }(\$)\end{array}$ & $\begin{array}{c}\text { Enrollment } \\
(\text { FTE })\end{array}$ & $\begin{array}{c}\text { Grant per } \\
\text { FTE }(\$)\end{array}$ & $\begin{array}{c}\text { Grant per FTE } \\
(\$ 1997)\end{array}$ \\
\hline $1982 / 83$ & $725,081,000$ & 78,677 & 9,215 & 14,551 \\
$1983 / 84$ & $703,968,000$ & 83,712 & 8,409 & 12,648 \\
$1984 / 85$ & $717,201,000$ & 86,519 & 8,290 & 12,110 \\
$1985 / 86$ & $756,260,000$ & 87,941 & 8,600 & 12,237 \\
$1986 / 87$ & $716,231,400$ & 90,743 & 7,893 & 10,861 \\
$1987 / 88$ & $688,254,400$ & 93,686 & 7,346 & 9,727 \\
$1988 / 89$ & $716,191,700$ & 96,208 & 7,444 & 9,603 \\
$1989 / 90$ & $755,016,700$ & 96,202 & 7,848 & 9,724 \\
$1990 / 91$ & $778,011,700$ & 97,823 & 7,953 & 9,321 \\
$1991 / 92$ & $807,974,872$ & 98,287 & 8,221 & 9,111 \\
$1992 / 93$ & $833,373,052$ & 102,592 & 8,123 & 8,879 \\
$1993 / 94$ & $826,155,450$ & 102,909 & 8,028 & 8,670 \\
$1994 / 95$ & $755,505,949$ & 103,141 & 7,325 & 7,808 \\
$1995 / 96$ & $715,761,719$ & 105,727 & 6,770 & 7,054 \\
$1996 / 97$ & $834,262,000$ & 107,842 & 7,736 & 7,890 \\
& & & &
\end{tabular}

Note: Operating grants for $1982 / 83$ to $1988 / 89$ have been adjusted to include Capital Renewal Grants; capital and operating grants were combined in 1990. Enrollment numbers from 1982/83 to 1988/89 have been adjusted to compensate for changing definitions of full-time equivalent students. 
resource strategy entitled, People and prosperity: A human resource strategy for Alberta (Government of Alberta, 1997). The document emphasizes the financial responsibility of individual Albertans and business for maintaining Alberta's postsecondary system. Government's role is limited to ensuring that bank-administered, loan-based student assistance is available.

Continuous learning and the updating of skills is a shared responsibility. The primary onus is on individual Albertans, but strategies are needed to help them access learning opportunities and obtain the skills and knowledge they need to be successful. Student assistance ensures that financial barriers do not act as a deterrent to Albertans pursuing adult learning. Alberta's schools, universities, colleges and technical institutes play a key role in our human resource strategy. Schools are responsible for providing education programs that develop individual potential and prepare young Albertans for daily living, the world of work and lifelong learning. Adult learning institutions have a responsibility to provide high quality, accessible learning opportunities to people who are preparing for careers and to those who wish to update their skills. Employers, employee groups and unions have a responsibility to facilitate learning opportunities in the workplace (Government of Alberta, 1997, p. 10).

This statement is the culmination of a series of similar statements. In 1993, Seizing opportunities: Alberta's new economic development strategy, noted:

From elementary grades to postsecondary training, education must give Albertans competitive skills to succeed in the evolving world economy. To do this, we need to increase private-sector participation in education and training at all levels (Government of Alberta, 1993, pp. 20-21).

More explicitly, the 1994 draft White Paper An agenda for change, stated:

Learning providers will be more responsive to the needs of the individual, community and the economy. They will solicit 
information from industry about the needs of the labour market and encourage employers to play a greater role in program design. There will be more emphasis on non-public revenue sources... (AECD, 1994b, p. 15).

Business and industry...will play an expanded role by becoming active participants in the adult learning system. They will have an enhanced role in providing advice to the system both in terms of overall direction and specific program design. Employers will take a greater role in job-specific training. Industry will also be expected to contribute more to the costs of education and training (AECD, 1994b, p. 16)

The subsequent White Paper, New directions for adult learning in Alberta, increased the provincial tuition cap from $20 \%$ of net institutional operating expenses to $30 \%$ in order to "...increase the responsibility of public postsecondary students for setting fees and (cover) the costs of learning to recognize the benefits of opportunities to learn" (AECD, 1994a, p. 13). New directions also reiterated the government's desire to increase private-sector investment in adult learning opportunities:

The department will work with other departments, governments and business, labour and industry organizations to stimulate greater private sector investment in on-the-job training. The department will provide industry with information it has gathered on anticipated human resource requirements, the relationship between learning opportunities and improved performance and productivity, as well as various formal and informal models for employee learning opportunities (AECD, 1994a, p. 9).

This collection of policy statements clearly demonstrates that the Government of Alberta is intent upon both decreasing its responsibility for providing funding to institutions, and increasing the funding provided by corporations and students. This agenda is advanced through the major changes to resource allocation undertaken in response to New directions and that are described below. 


\section{Higher education as labour market training}

Through the 1990s, government documents increasingly framed higher education as a source of labour market training. This trend first become evident in Towards 2000 Together:

A highly skilled workforce will be essential for Alberta to succeed in the knowledge intensive world of the 21 st century. Consequently, new approaches may be required to more effectively bring together economic and educational priorities. These approaches may require a shift in the responsibilities borne by government, the private sector and the individual (Government of Alberta, 1992, p. 10).

Subsequently, the document of 1993, Seizing opportunities: Alberta's new economic development strategy, noted:

From elementary grades to postsecondary training, education must give Albertans competitive skills to succeed in the evolving world economy. To do this, we need to increase private-sector participation in education and training at all levels. Business can foster the entrepreneurial attitudes and skills necessary to increase competitiveness... (Government of Alberta, 1993, pp. 20-21).

In February 1994, the government's first business plan, $A$ better way: A plan for securing Alberta's future, presented the following objective:

...(to) increase the responsiveness of education and training programs to individual Albertans and their communities with priority given to contributing to Alberta's economy and preparation for the labour market (Government of Alberta, 1994, p. 3).

In March 1994, the draft White Paper, An agenda for change, was released. It noted:

Adult learning will continue to address the social, intellectual and cultural needs of Albertans. However, the institutions will be expected to give renewed emphasis to programming to respond to the needs of the economy (AECD, 1994b, p. 16). 
Industry and postsecondary institutions will be encouraged to forge stronger links with each other to ensure the relevance of education and training to the work force and economy. The employability of graduates and their ability to become entrepreneurs will be emphasized (AECD, 1994b, p. 16).

Substantial shifts in the role of various stakeholders were outlined:

Learning providers will be more responsive to the needs of the individual, community and the economy. They will solicit information from industry about the needs of the labour market and encourage employers to play a greater role in program design. There will be more emphasis on non-public revenue sources... Where appropriate, private learning providers will be accredited so that they may play an expanded role in the adult learning system (AECD, 1994b, p. 15).

Business and industry... will play an expanded role by becoming active participants in the adult learning system. They.will have an enhanced role in providing advice to the system both in terms of overall direction and specific program design. Employers will take a greater role in job-specific training. Industry will also be expected to contribute more to the costs of education and training (AECD, 1994b, p. 16).

Several initiatives undertaken in response to New directions focus on increasing labour market outcomes. These include:

- The creation a new credential (the applied degree is described below) designed to "meet the needs of the learner and the economy, and involve employers in program design, delivery and the costs of the work experience component" (AECD, 1994a, p. 11).

- A funding envelope to expand student spaces in disciplines with high labour market demand. When coupled with declining base grants, this means new student spaces will only be opened in programs with high labour market demand.

- A funding envelope that rewards institutions to achieving outcomes such as high levels of graduate employment. 
Alberta's 1997 human resource strategy, People and prosperity, continues this focus on education as labour-market training when it states:

Continuous learning and the updating of skills is a shared responsibility. The primary onus is on individual Albertans, but strategies are needed to help them access learning opportunities and obtain the skills and knowledge they need to be successful...Schools are responsible for providing education programs that develop individual potential and prepare young Albertans for daily living, the world of work and lifelong learning. Adult learning institutions have a responsibility to provide high quality, accessible learning opportunities to people who are preparing for careers and to those who wish to update their skills. Employers, employee groups and unions have a responsibility to facilitate learning opportunities in the workplace (Government of Alberta, 1997, p. 10).

Taken together, this collection of policy statements clearly demonstrates that the Government of Alberta views higher education as a source of labour-market training and is intent upon increasing institutional responsiveness to training needs. A similar trend towards aligning the activities of higher education with the needs of the marketplace is evident in discussion of university research.

\section{Higher education as a source of knowledge and technology}

Government policy in the 1990 s has also encouraged postsecondary institutions to increase the volume of knowledge and technology that they transfer to the private sector. Towards 2000 Together stated that one of Alberta's economic objectives involved the following research component: "...to encourage the development and application of science, technology and research to enhance Alberta's domestic and international economies" (Government of Alberta, 1992, p. 6).

In 1993, Seizing opportunity: Alberta's new economic development strategy, noted that Alberta would develop the following orientation:

...substantially increase the focus on commercialization of research and development, through activities which include the development of an industry-based technology 
commercialization organization to focus on market research, prototype development and initiation of management teams capable of building a company around a technology (Government of Alberta, 1993, p. 10).

In February 1994, the government's first business plan, $A$ better way: A plan for securing Alberta's future, noted that one objective is to: “...increase the commercial applications of Alberta inventions and innovations and improve the effectiveness of government-funded research and development activities" (Government of Alberta, 1994, p. 3). In support of this goal, government promised to:

...encourage quality research, support research programs with clear commercial potential and which add to the competitiveness of Alberta's industries (and) focus the efforts of the Alberta Research Council on biotechnology, energy breakthrough technologies, environmental technologies, forest products, information technologies, manufacturing and pulp and paper (Government of Alberta, 1994, p. 4).

The expected results include three components:

Research and development activities in Alberta are expanded, there is an increase in successful commercialization endeavors stemming from research, and a corresponding growth in Alberta's economy (Government of Alberta, 1994, p. 4).

Although the White Paper, New directions for adult learning in Alberta, largely ignored university research, it did trigger a review of university research in Alberta. This 1995 review proposed that any university research policy must seek:

1. to contribute to human resource development by training a highly educated and competitive workforce, providing for a new generation of researchers, and providing for the broad education of Albertans in general; and

2. to contribute to the cultural, social and economic development of Alberta through access to and the development of new knowledge (AECD, 1995a, p. 28). 
By and large, Alberta's 1996 policy framework for university research (AECD, 1996g) adopted these goals and created the Research Excellence Envelope to allocate funding. This was subsequently supplemented by the Intellectual Infrastructure Partnership Program. Both of these funding envelopes advantage disciplines and research topics that are relevant to the needs of the marketplace and that can attract privatesector sponsorship.

\section{Summary}

The Government of Alberta has consistently reduced public funding of postsecondary education, while at the same time it has advocated increasing institutional revenues coming from the private sector and students. Government policy also encourages greater institutional responsiveness to the training demands of the labour market and increasing the amount of knowledge and technology transferred by institutions to the private sector. The next section will outline the changes in resource allocation that followed the 1994 introduction of a White Paper on postsecondary education. The policy initiatives that flow from the White Paper are clearly designed to achieve the three objectives outlined above. In particular, changes in resource allocation and funding sources are meant to drive institutions toward becoming increasingly responsive to the programming demands of students and corporations, as well as engaging in business-education partnerships designed to develop and transfer knowledge and technology to the private sector.

\section{RESOURCE ALLOCATION IN ALBERTA'S POSTSECONDARY SYSTEM}

Alberta was incorporated as one of Canada's (now) 10 provinces and 3 territories in 1905. In 1996, Alberta had a population of 2.8 million. Approximately 1.7 million of these inhabitants were equally divided between the two major urban centers, Edmonton and Calgary (Statistics Canada, 1999a, 1999b). Alberta's public postsecondary system enrolls approximately 123,000 students in 4 universities, 2 technical institutes, 16 colleges, 5 religiously affiliated, not-for-profit university-colleges and 
the Banff Centre (AECD, 1998a). Alberta also has a large apprenticeship training program and over 90 private vocational schools.

\section{Postsecondary funding in Alberta, 1945 to 1994}

Alberta's postsecondary system expanded rapidly after the Second World War. Federal grants to universities began in 1951. These were replaced in 1966 by a direct federal transfer to the province which covered approximately half of the cost of postsecondary education (AECD, 1995b). Alberta allocated funding based upon the number of full-time students and differences in program costs. This approach to funding is called "formula-based budgeting". Designed to ensure funding adequacy, equity and stability, formula-based budgeting (Caruthers, Marks \& Walker, 1994; Massy, 1996a) mathematically ties allocations to specific criteria (e.g., $\$ 6200$ per full-time equivalent student) Critics believe formula funding creates inter-institutional competition for the basis of allocations (e.g., students, programs, physical plants) but provides no incentive for institutions to improve functioning (Albright \& Gilleland, 1994; Sells, 1994).

The Ministry of Advanced Education was established in 1971. It assumed responsibility for general postsecondary education, as well as the agricultural, technical and vocational sectors. In 1973, formula funding gave way to" incremental funding." Incremental budgeting changes basic operating and capital budgets annually (Epper, 1994; Layzell \& Caruthers, 1995). These changes could include across-the-board changes (e.g., an annual increase of $2 \%$ to all budget line items), or more specific changes (e.g., changing, adding or deleting specific line items). A threeyear operating grant plan (based on projected enrollment for the 1973-76 period) was developed, and from 1977 to 1991, each institution's operating grant was adjusted to compensate for inflation. Operating grants could be adjusted for new programs, for the operating costs of new space, and for special circumstances. Incremental budgeting perpetuates resource distribution patterns and is criticized both for its irrationality, as well as its encouragement of budget maximizing behavior by bureaucrats (Osbourne \& Gaebler, 1992). Massy (1996b) asserts that attributing responsibility for the financial health of units to central administrators 
politicizes allocations and drives the institutional desire to maximize revenue so as to avoid intra-institutional conflict over resources.

Additional funding adjustments were allocated through "funding envelopes" during the 1980s. "Funding envelopes" are a method of resource allocation called incentive funding. Incentive funding makes available additional funds contingent upon institutions engaging in specific activity (Epper, 1994). The structure and criteria of incentive funding allow governments to set goals, but the specific methods for achieving those goals are left to the applicant (Carter, 1989; Holland \& Berdahl, 1990). For example, a government may wish to create an additional 2000 spaces in a particular discipline; institutions could then be asked to bid in a competitive manner upon the creation of some or all of these spaces according to a series of criteria. This approach to incentive funding is called initiative funding and indirectly links funding with performance since the allocation is made prior to the achievement of results (Serban, 1998). A second type of incentive funding is categorical funding where all institutions are eligible to access funds for specific purposes as long as they abide by the criteria. For example, a government may set aside funding for each institution (with the amount perhaps determined by enrollment) to use for physical plant upgrades, but it may also attach such conditions as requiring institutions to match a certain portion of the money.

A supplementary enrollment growth funding envelope was introduced in FY 1982/83. This envelope provided an incremental amount for each additional full-time equivalent (FTE) student based upon marginal increases in enrollment over the 1981/82 year. Between FY 1982/83 and $1991 / 92$, enrollment increased by approximately 29,000 students. In 1991/92, this envelope was eliminated.

By 1981-82, a capital funding formula to address the maintenance of furnishings and equipment, renovations and alterations, and site and utility maintenance was enacted. Funding was based upon facilities' areas, the replacement value of each institution's assets, and useful lifetimes in various asset categories (AECD, 1995b). In 1990/91, the formula was discontinued and each institution's allocation continued at the 1986-87 level. In 1993/94, the department rolled capital grants (fixed at 1986/87 levels) and operating grants (fixed at 1991/92 levels) together. 


\section{Postsecondary funding in the 1990s}

In 1993, Alberta began a consultation process to outline the future direction of postsecondary education. This was a period of fiscal restraint as the government reduced public expenditures to reduce the provincial budget deficit. It was also a time of public-sector reform that included privatization of government services as well as the introduction of business plans and performance measures. In October 1994, the government released the White Paper New directions for adult learning in Alberta (AECD, 1994a). This paper outlined a number of measures including:

- a three-year, $21 \%$ reduction in government funding

- an increase in tuition fees

- the introduction of several funding envelopes

- a performance-based funding mechanism.

Government funding and tuition, 1982 to 1997 . The three-year, $21 \%$ reduction to institutional base grants that began in 1994 perpetuated a long-term decline in public funding of postsecondary education (AECD, 1994a). As outlined in Table 1, when the $21 \%$ reduction is combined with rising enrollments and sluggish funding growth through the 1980 s, per-student, real dollar $(1997=100)$ government grant-based revenue fell from $\$ 14,551$ in $1982 / 83$ to $\$ 7890$ in $1996 / 97$ - a reduction of $45.8 \%$ over 15 years (Shillington, 1998).

Additional pressure will be exerted on Alberta's higher education system by an expected increase in enrollment of between 23,000 and 37,000 students between 1997 and 2005 (AECD, 1997a). Although some additional funding has been committed to manage this growth, projections suggest that per-student funding levels will continue to decline (ACIFA and CAFA, 1998). This is consistent with the government's intention of reducing public funding.

To offset declining government funding, tuition has been increased. Alberta's tuition cap represents the percentage of net operating expenditures for credit programming that tuition can make up. The cap increased from $12 \%$ in 1989 to $20 \%$ in 1991 to $30 \%$ in 1994 . The $30 \%$ cap cannot be reached prior to $2000 / 01$. Annual increases are limited to $\$ 215$ 
(indexed to inflation) and made up $21.3 \%$ of institutional revenue in 1996/97, up from 14.9\% in 1993/94 (AECD, 1994a, 1998a). As outlined in Table 2, reapportioning costs by increasing tuition means real-dollar, per-student, grant- and tuition-based revenue declined by only $36 \%$ between 1982/83 and 1997/98 (ACIFA and CAFA, 1998).

Following the release of New directions, the government introduced a series of funding envelopes designed to address key issues and/or elicit specific performances from institutions.

Access Fund. The Access Fund was established to finance innovative, cost-effective methods of increasing student spaces while meeting labourmarket needs (AECD, 1994a). Originally, $\$ 47$ million was allocated to create 10,000 additional spaces between 1994 and 1997 . The $\$ 4700$ allocated per student (as compared to the $\$ 8670$ provided per-student through base grants in 1993/94) was designed to eliminate inefficiencies within the system (AECD, 1996a). The Access Fund added 10,601 full-time equivalent spaces at an annual cost of roughly $\$ 2900$ per student (AECD, 1996b) with heavy emphasis on expanding opportunities in market-proximate disciplines. Science programs saw the largest growth in new full-time equivalent (FTE) spaces with 2350 FTEs. Other programs also grew: computing science ( 717 FTEs), agriculture (536 FTEs), environmental studies (608 FTEs), technologies (245 FTEs), manufacturing (248 FTEs), business (624 FTEs), management (490 FTEs) and the humanities (889 FTEs) (AECD, 1996c). In January 1999, \$51 million from a new Access Fund was allocated to increase student spaces in information and communications technology (ICT) programs (Treasury, 1999).

During the first Access Fund, 91 of 600 applications were approved and these included eight "applied degrees." A new credential in Alberta, applied degrees add one year of classroom instruction and one year of supervised work experience to existing two-year diploma programs offered at colleges and technical institutes (AECD, 1998b). According to New directions, "applied degree programs must meet the needs of the learner and the economy, and involve employers in program design, delivery and the costs of the work experience component" (AECD, 1994a, p. 11). A review of the applied degree program has resulted in its continuation and expansion. 
Table 2

Per-student, real-dollar grant- and tuition-based revenue, 1982 to 1997.

\begin{tabular}{lcrrrr}
\hline Year & $\begin{array}{c}\text { Tuition } \\
\text { Revenues }(\$)\end{array}$ & $\begin{array}{c}\text { FTE } \\
\text { Students }\end{array}$ & $\begin{array}{c}\text { Tuition } \\
\text { per FTE }(\$)\end{array}$ & $\begin{array}{c}\text { Tuition } \\
\text { per FTE } \\
(\$ 1997)\end{array}$ & $\begin{array}{c}\text { Grant } \\
\text { \& Tuition } \\
\text { per FTE } \\
(\$ 1997)\end{array}$ \\
\hline $1982 / 83$ & $47,714,932$ & 78,677 & 606 & 947 & 15,498 \\
$1983 / 84$ & $51,897,058$ & 83,712 & 620 & 932 & 13,580 \\
$1984 / 85$ & $60,591,662$ & 86,519 & 700 & 1026 & 13,136 \\
$1985 / 86$ & $66,694,708$ & 87,941 & 758 & 1079 & 13,316 \\
$1986 / 87$ & $71,033,604$ & 90,743 & 783 & 1077 & 11,938 \\
$1987 / 88$ & $79,734,049$ & 93,686 & 851 & 1127 & 10,854 \\
$1988 / 89$ & $86,448,949$ & 96,208 & 899 & 1160 & 10,763 \\
$1989 / 90$ & $97,984,558$ & 96,202 & 1,019 & 1237 & 10,961 \\
$1990 / 91$ & $110,368,830$ & 97,823 & 1,128 & 1322 & 10,632 \\
$1991 / 92$ & $110,426,647$ & 98,287 & 1,124 & 1245 & 10,356 \\
$1992 / 93$ & $129,069,035$ & 102,592 & 1,258 & 1375 & 10,254 \\
$1993 / 94$ & $154,268,148$ & 102,909 & 1,499 & 1619 & 10,289 \\
$1994 / 95$ & $163,852,433$ & 103,141 & 1,589 & 1694 & 9,502 \\
$1995 / 96$ & $188,694,713$ & 105,727 & 1,785 & 1860 & 8,914 \\
$1996 / 97$ & $215,564,830$ & 107,842 & 1,999 & 2040 & 9,930
\end{tabular}

Note: Tuition revenues for 1982/83 to 1990/91 have been adjusted to compensate for the impact of the new tuition fee policy implemented in 1991/92. Tuition revenues per FTE reflect an average of university tuition (which is higher than the average shown) and college and technical institute tuition (which is lower than the average shown). Enrollment numbers from $1982 / 83$ to $1988 / 89$ have been adjusted to compensate for changing definitions of full-time equivalent students. 
Learning Enhancement Envelope. The Learning Enhancement Envelope (LEE) provides $\$ 10$ million per year from $1996 / 97$ to $2001 / 02$ to encourage institutions to develop alternative opportunities for adult learners with technology (AECD, 1996d). LEE funding will "advance the development of a province-wide virtual learning system to ...bring about a new order of cooperation among postsecondary institutions as they become collaborative members of technology-enhanced learning networks" (AECD, 1996d, p. 9). LEE funding can be used to:

- Adapt curriculum for new, technologically supported models of learning for students who may be on campus, at a community site, at home or at a workplace and test these models.

- Increase the number of courses and programs that are available to students who need access to opportunities from a distance.

- Design training that will help students, support staff and instructors to acquire the skills necessary to study and work in settings that integrate technology with learning.

- Conduct research that will add knowledge about the integration of technology with teaching and learning.

- Devise and test models of learner support that will be required to successfully integrate technology with learning.

- Purchase equipment and infrastructure that are required to increase access or to deliver curriculum using technology (AECD, 1996d, pp. 7-8).

According to the government, "priority will be given to initiatives that demonstrate collaboration among institutions and other organizations" such as employers (AECD, 1996e, p. 10).

Research Excellence Envelope. The Research Excellence Envelope annually distributes $\$ 2$ million (AECD, 1996f) to address the declining research capacity noted in a 1995 review (AECD, 1995c). Items eligible for funding through the Research Excellence Envelope include:

- the purchase or upgrading of particular research equipment;

- adaptation/establishment of laboratory or other appropriate space; 
- the purchase of specialized or enhanced computing equipment or software;

- particular library acquisitions or enhancements;

- research assistantships and/or technical support;

- travel funds for research purposes or unusually expensive research supplies. (AECD, 1997c, p. 1).

Intellectual Infrastructure Partnership Program. The Research Excellence Envelope was supplemented in 1997 by the Intellectual Infrastructure Partnership Program (I2P2) that commits $\$ 45$ million over three years (AECD, 1997b). The rationale for the introduction of I2P2 was:

The development and application of new knowledge has become central to competitive success with the global economy. Universities and research hospitals are the key to:

- the development of new knowledge and technologies;

- the transfer of new knowledge and technologies to the private sector and communities;

- the development and retention of highly trained and knowledgeable personnel in the province; and

- employment growth and wealth creation related to the development of new technologies and knowledge (AECD, 1997d, p. 1).

12P2 allows institutions to invest in infrastructure in order to attract and retain top researchers and to secure additional infrastructure funding from the Canada Foundation for Innovation. The I2P2 program emphasizes expanding research capacity in health, the natural sciences, and engineering and environmental sciences. Applications from outside those fields must address Alberta's economy and/or quality of life. As a condition of funding, "(e)ach application will be required to provide evidence of a significant financial commitment made by a partner or partners from the private sector (business or non-profit sector) towards the cost of the project" (AECD, 1997d, p. 3).

Infrastructure Renewal Envelope. Beginning in 1996, the Infrastructure Renewal Envelope provided $\$ 23$ million over three years 
to modernize and update equipment (AECD, 1996h). Following a June 1997 facilities evaluation that outlined $\$ 350$ million in required infrastructure maintenance by 2002 (AECD, 1997e), an additional $\$ 105$ million was allocated over three years (AECD, 1997f). Of that $\$ 105$ million, $\$ 50$ million will be allocated on the basis of the facilities evaluation. The remainder will be allocated on the basis of system-wide needs, as well as the project proposals submitted to government. Institutions are expected to contribute between 20 and $40 \%$ of project costs (depending on an institution's location) from existing budgets or non-governmental sources. The 1998 provincial budget allocated \$20 million in one-time funding from the Infrastructure Renewal Fund (AECD, 1998c) to expand Albertans' access to library resources. One outcome of this project will be to link together postsecondary and public libraries throughout the province to increase user access to materials (AECD, 1999).

Performance Envelope. The final funding envelope mandated by New directions was the Performance Envelope which annually allocates $\$ 15$ million ( $\$ 23$ million beginning in 2000) based upon institutional performance as assessed by nine performance indicators (AECD, 1997g; Treasury, 1999). Performance-based funding links future funding to measurable outcomes, thereby making funding contingent upon accomplishments (Layzell \& Caruthers, 1995; Peterson, Erwin \& Wilson, 1977). This approach is distinct from incentive funding because funding follows performance, rather than preceding it. By devolving responsibility for goal achievement to institutions, administrators alter the attribution of financial responsibility that underlies incremental budgeting: institutions (and individual programs) are responsible for earning adequate funding by producing an acceptable performance. Not unlike incentive funding, performance funding tends to function on the edges of, or in addition to, base allocations so as not to damage funding adequacy, stability and equity (Bateman \& Elliott, 1994; Coulter \& Moore, 1987). Underlying the use of performance-based funding is the belief that institutions should and must be forced to re-examine basic spending (Epper, 1994), and that altering institutional spending patterns is desirable (Brown \& Wolf, 1993; Massy \& Hulfactor, 1993). This performance approach may not fully appreciate that existing funding patterns 
represent negotiated solutions which ensure that multiple and often conflicting objectives are achieved (Carter, 1989; Caruthers et al., 1994).

The learning component's five indicators are broken down into three categories based upon New direction's key goals of responsiveness, accessibility and affordability (AECD, 1994a, 1997g). Institutional responsiveness to the needs of learners and to provincial social, economic and cultural needs is assessed through an examination of the employment rates of graduates and graduates' satisfaction with the quality of their educational experience. Assessment of changes in full-load equivalent (FLE) enrollment based on a three-year rolling average indicates institutional progress towards higher levels of accessibility (i.e., increasing the number of student spaces). This indicator is adjusted for institutional location and recognizes that urban institutions have historically been better able to maintain stable enrollments because of a larger population base (AECD, 1996i). Institutions' success at maintaining affordability (i.e., providing quality learning opportunities to the greatest number of Albertans at a reasonable cost to the learner and taxpayer) is indicated by an analysis of administrative expenditures and outside revenue generated

The research component has four indicators and is only used by research universities (AECD, 1996i). Council success rates identify national granting council awards (MRC, NSERC and SSHRC) per fulltime faculty member. Such analysis is done for peer institutions across Canada. Citation impact is the expressed ratio of citations to published papers. The Institute for Scientific Information produces a database of summary publications and citation statistics that reflect research performance in the sciences and social sciences for Canadian universities. This database includes citations for 6000 peer-reviewed journals. Community- and industry-sponsored research per full-time faculty member is derived from Statistics Canada and the Canadian Association for University Business Officers data. Research enterprise involves the total sponsored research revenues generated, and is expressed as a proportion of the government grant. This indicator is meant to capture the degree of "leverage" an institution has established through its operations grant by raising research funding. 
During the two-year pilot, $\$ 15$ million was allocated annually from the Performance Envelope. In 1997, this money was distributed in two ways. First, each institution received a net system-wide award of $1 \%$ of its operating grant to reward system-wide improvements in productivity. Second, institutions were rewarded based upon their performance: 8 (of 21 ) institutions received an additional award of $1.5 \%$ based upon their performance, 9 institutions received an additional .75\% and four institutions received no performance-based funding (AECD, 1997g). The percent of operating grants received as a performance award in 1998 decreased slightly (to $1.26 \%$ and $.63 \%$ ) because, while institutional performance improved, the total funding for performance awards available remained fixed at $\$ 15$ million (AECD, 1998d). These awards accumulate over time (i.e., are added to institutions' revenues the next year) (Treasury, 1998).

\section{Summary}

Alberta's postsecondary institutions have seen an ongoing decline in per-student, real-dollar government grants since 1982. These changes are designed to achieve government policy objectives that include diversifying institutions' funding bases, increasing the alignment of higher education with labour market training demands and increasing the transfer of knowledge and technology to the private sector. The following section describes how resource allocation is used to achieve these ends.

\section{USING RESOURCE ALLOCATION TO OPERATIONALIZE POLICY OBJECTIVES}

The significant changes to postsecondary funding in Alberta during the 1990s advance the government's three policy objectives:

1. The financial responsibility for higher education needs to be reapportioned. Decreasing public funding pressures postsecondary institutions to increase funding derived from students and the private sector and thereby reapportions financial responsibility for higher education.

2. Higher education should provide labour market training. Government policy clearly frames higher education as a 
source of labour market training and directs institutions to be increasingly responsive to the market by providing vocational outcomes.

3. Higher education should develop and transfer knowledge and technology to the private sector. Government policy pressures postsecondary institutions to commercialize research.

By altering the source of institutional funding and how a portion of the remaining government funding is allocated, the government can generate substantial pressure on institutions to align their teaching and research functions with the needs of the market. Tuition revenue increases the importance of students who, facing pressure to realize an economic gain from their education to defray rising tuition costs, desire labour market outcomes from higher education. Revenue from corporate partnerships also pressures institutions to provide well-trained graduates and to commercialize the results of their research. Changes in how the government allocates funding facilitates this process: declining base grants create an incentive for institutions to secure additional funding from these external revenue sources. Resource hungry institutions are also eager to accept government funding provided through funding envelopes - envelopes that also pressure institutions to align their activities with the needs of the market.

The pressure on institutions to align their activities with the needs of the market represents a substantial erosion of institutional autonomy. Attempts to impose such an agenda would entail a substantial political cost. The same objective can be attained at a much lower political cost, however, through simple restructuring of resource allocation such that institutions have no choice but to accept the agenda in order to access the resources needed to survive. This approach to managing higher education is consistent with Neave's (1988) evaluative state. The evaluative state (also called contract government) devolves goal-attainment responsibility to individuals and institutions while government maintains control of the system by structuring resource allocation (Dominelli \& Hoogvelt, 1996).

The evaluative state can be operationalized in higher education through what Slaughter and Leslie (1997) term academic capitalism. 
Academic capitalism is the alignment of the activities of higher education with the needs of the marketplace. It entails institutions and academics engaging in market (i.e., for-profit activities) and market-like (i.e., competing for funding) behavior such as seeking grants, launching spinoff companies, building endowments, raising tuition and entering into business-education partnerships. The successful introduction of academic capitalism is premised upon resource dependence theory. This theory suggests that organizations depend upon their environment for key resources and that organizational behaviour is a response to the actions of external agents who control organizational resources (Pfeffer, 1992; Pfeffer \& Salancik, 1978). Substantial changes in resource availability destabilizes organizations and results in organizational adaptation to ensure survival.

Academic capitalism, therefore, can be induced by various governmental strategies: decreasing public transfers of undesignated funding; introducing designated funding envelopes that reward market and market-like behavior; and pressuring institutions to develop non-government sources of funding (e.g., corporate partnerships, tuition, etc.). Decreasing the amount of undesignated public funding forces institutions to seek new, generally non-governmental, sources of funding and, therefore, makes them more dependent upon (ergo responsive to) the needs and interests of these sources of external funding. These changes in resource allocation decrease institutional autonomy by encouraging a growing alignment between the needs of the market and the activities of postsecondary institutions.

\section{IMPLICATIONS OF CHANGING POSTSECONDARY FUNDING}

The changes to postsecondary funding in Alberta since 1994 are designed to achieve government goals such as reducing government spending, increasing the vocational outcomes of postsecondary institutions, and increasing the transfer of knowledge and technology by institutions to the private sector. This suggests a number of implications:

1. Resource allocation in Alberta's postsecondary system is designed to achieve a specific set of goals. Given the appropriateness of these methods for achieving government goals 
(i.e., decreasing government funding and increasing the alignment of higher education with the needs of the marketplace), it seems unlikely that the government will substantially alter how it funds higher education until its goals change.

2. Framing higher education as labour-market training justifies increasing tuition levels. If postsecondary education is primarily a means for students to increase their earning potential, it follows that students should absorb an increasing portion of the costs of higher education. This justifies rising tuition and student debt levels. Questions of accessibility then revolve around having an adequate number of seats available to students. Whether or not students can afford to attend is no longer at issue in discussions of accessibility because affordability can always be achieved through student loans.

3. Institutional autonomy is a barrier to maximizing the economic benefits of higher education. Allowing institutions and academics to determine what programs they will offer and what research they will undertake impedes the effect of market forces to determine what sort of graduates are required and what research is needed. Government policy has decreased institutional autonomy by pressuring institutions to offer programs in areas with high labour-market demand and to conduct research on topics that result in economic benefits. Declining government funding also encourages institutions to increase their reliance on student tuition, thereby allowing students greater opportunity to adopt the stance of customers.

4. Permanent employees hinder institutional responsiveness to the needs of the market. The use of full-time and permanent employees constrains institutional flexibility (particularly in regards to creating and dismantling programs) and increases institutional costs. The growing use of part-time and/or limited-term faculty is an institutional response to enrollment growth outpacing funding increases. This employment pattern 
will increase with time, dependent upon the availability of suitable instructional personnel.

Strategies designed to alter resource allocation in Alberta's higher education system need to address the policy instruments that are resulting in these outcomes. It is also necessary to explore and address the broader social, economic and political forces that legitimate government policy objectives.

\section{References}

ACIFA \& CAFA. (1998). Brief to the Standing Policy Committee on Education and Training. March 16. Edmonton, AB: Alberta Colleges \& Institutes Faculties Association and the Confederation of Alberta Faculty Associations.

AECD. (1994a). New directions for adult learning in Alberta. White Paper. October. Edmonton, AB: Advanced Education and Career Development.

AECD. (1994b). An agenda for change. Draft White Paper. March. Edmonton, AB: Advanced Education and Career Development.

AECD. (1995a). University research in Alberta: A policy framework. Edmonton, AB: Advanced Education and Career Development.

AECD. (1995b). A proposed performance-based funding mechanism for Alberta's public postsecondary education system. June 26. Edmonton, AB: Advanced Education and Career Development.

AECD. (1996a). Over 10,000 new places created in the postsecondary education system, Access Fund exceeds goals. Press release. March 29. Edmonton, AB: Advanced Education and Career Development.

AECD. (1996b). Access Fund exceeds goals: Over 10,000 new places created. Innovations in adult learning. Edmonton, AB: Advanced Education and Career Development. 4-5.

AECD. (1996c). Over 10,000 new places created in the postsecondary education system, Access Fund exceeds goals. Backgrounder. March 29. Edmonton, AB: Advanced Education and Career Development.

AECD. (1996d). Enhancing Alberta's adult learning system through technology: Policy guidelines and procedures for the Learning Enhancement Envelope. June 17. Edmonton, AB: Advanced Education and Career Development. 
AECD. (1996e). LEE guidelines. Edmonton, AB: Advanced Education and Career Development.

AECD. (1996f). Jack W. Ady announces a policy framework for Alberta's university research system. Edmonton, AB: Advanced Education and Career Development.

AECD. (1996g). Fostering excellence: A policy framework for Alberta's university research system. Edmonton, AB: Advanced Education and Career Development.

AECD. (1996h). Jack W. Ady announces a policy framework for Alberta's university research system. Press release. Edmonton, AB: Advanced Education and Career Development.

AECD. (1996i). Encouraging excellence and rewarding success in Alberta's public adult learning system: A proposal for implementing a performance funding envelope. December. Edmonton, AB: Advanced Education and Career Development.

AECD. (1997a). Minister's forum on adult learning. Briefing materials. Edmonton, AB: Advanced Education and Career Development.

AECD. (1997b). Intellectual Infrastructure Partnership Program will strengthen research excellence and competitiveness of universities and research hospitals. Press release. October 14. Edmonton, AB: Advanced Education and Career Development.

AECD. (1997c). 1997/98 Research Excellence envelope reporting guidelines. Edmonton, $\mathrm{AB}$ : Advanced Education and Career Development.

AECD. (1997d). Intellectual Infrastructure Partnership Program. Backgrounder. October 16. Edmonton, AB: Advanced Education and Career Development.

AECD. (1997e). General facilities evaluation. Edmonton, AB: Advanced Education and Career Development.

AECD. (1997f). \$105 million for infrastructure renewal for Alberta universities, public colleges and technical institutes. Press release. August 14. Edmonton, AB: Advanced Education and Career Development.

AECD. (1997g). Rewarding progress towards goals: Highlights of Alberta's performance envelop funding. July 31. Edmonton, AB: Advanced Education and Career Development.

AECD. (1998a). Annual report, 1997/98. Edmonton, AB: Advanced Education and Career Development. 
AECD. (1998b). Applied degree evaluation advisory committee: Report and recommendations. July. Edmonton, $\mathrm{AB}$ : Advanced Education and Career Development.

AECD. (1998c). Adult learning institutions to receive $\$ 20$ million in Knowledge Network grants. Press release. November 23. Edmonton, AB: Advanced Education and Career Development.

AECD. (1998d). $\$ 15$ million rewards postsecondary excellence. Press release. June 30. Edmonton, AB: Advanced Education and Career Development.

AECD. (1999). Albertans' access to library resources and information getting easier. Press release. January 21. Edmonton, AB: Advanced Education and Career Development.

Albright, B.N., \& Gilleland, D.S. (1994). A clean slate: Principles for moving to a value-driven higher education funding model. In R.M. Epper (ed.), Focus on the budget: Rethinking current practice, state policy and college learning. Denver, CO: Education Commission of the States. 7-22. ERIC Document Reproduction Service. ED 375790.

Bateman, M., \& Elliott, R.W. (1994). An attempt to implement performance-based funding in Texas higher education: A case study. In R.M. Epper (ed.), Focus on the budget: Rethinking current practice, state policy and college learning. Denver, CO: Education Commission of the States. 41-52. ERIC Document Reproduction Service. ED 375790.

Brown, M.A., \& Wolf, D.M. (1993). Allocating budgets using performance criteria. In P.G. Altbach \& D.B. Johnstone (eds.), The funding of higher education: International perspectives, (173-184). New York, NY: Garland.

Carter, N. (1989). Performance indicators: Backseat driving or hands off control? Policy and Politics, 17(2). 131-138.

Caruthers, J.K., Marks, J.L., \& Walker, J.K. (1994). Important safeguards in funding processes for public higher education. In R.M. Epper (ed.), Focus on the budget: Rethinking current practice, state policy and college learning. Denver, CO: Education Commission of the States. 53-63. ERIC Document Reproduction Service. ED 375790.

Coulter, W.R., \& Moore, A.H. (1987). Utilization of performance indicators for financing at state-level in the United States: The Ohio case. International Journal of Institutional Management in Higher Education, 11(2). 195-207.

Dominelli, L., \& Hoogvelt, A. (1996). Globalization, contract government and the Taylorization of intellectual labor in academia. Studies in Political Economy, 49, 71-100. 
Epper, R.M. (1994). Introduction. In R.M. Epper (ed.), Focus on the budget: Rethinking current practice, state policy and college learning. Denver, CO: Education Commission of the States. 1-6. ERIC Document Reproduction Service. ED 375790.

Government of Alberta. (1992). Towards 2000 together: A discussion paper on Alberta's economic options and choices. Edmonton, AB: Author.

Government of Alberta. (1993). Seizing opportunity: Alberta's new economic development strategy. Edmonton, AB: Author.

Government of Alberta. (1994). A better way: A plan for securing Alberta's future. February. Edmonton, AB: Author.

Government of Alberta. (1997). People and prosperity: A human resource strategy for Alberta. February. Edmonton, AB: Author.

Holland, B.A., \& Berdahl, R.O. (1990). Green carrots: A survey of state use of fiscal incentives for academic quality. Paper presented at the Annual General Meeting of the Association of the Study of Higher Education. November 1-4. Portland.

Layzell, D.T., \& Caruthers, J.K. (1995). Performance funding at the state level: Trends and prospects. Paper presented at the Annual Meeting of the Association for the Study of Higher Education. November 2. Orlando. ERIC Document Reproduction Service. ED 391406.

Massy, W.F. (1996a). Introduction. In W.F. Massy (ed.), Resource allocation in higher education, (1-13). Ann Arbor, MI: University of Michigan Press.

Massy. W.F. (1996b). Reengineering resource allocation systems. In W.F. Massy (ed.), Resource allocation in higher education, (15-47). Ann Arbor, MI: University of Michigan Press.

Massy, W.F., \& Hulfactor, M.C. (1993). Optimizing allocation strategy. In P.G. Altbach \& D.B. Johnstone (eds.), The funding of higher education: International perspectives, (25-44). New York. NY: Garland.

Neave, G. (1988). On the cultivation of quality, efficiency and enterprise: An overview of recent trends in higher education in Western Europe, 1986-1988. European Journal of Education, 23(1/2). 7-23.

Osborne, D., \& Gaebler, T. (1992). Reinventing government: How the entrepreneurial spirit is transforming the public sector. Don Mills, ON: Addison-Wesley.

Peterson, M.W., Erwin, J.M., \& Wilson, R. (1977). State performancebased budgeting. In J.K. Folger (ed.), Increasing public accountability in higher education. New Directions for Institutional Research, 4(4), 1-34. 
Pfeffer, J. (1992). Managing with power: Politics and influence in organizations. Boston, MA: Harvard Business School Press.

Pfeffer, J., \& Salancik, G.R. (1978). The external control of organizations: A resource dependence perspective. New York, NY: Harper \& Row.

Sells, K.R. (1994). Linking budgeting to academic planning: The Wisconsin case. In R.M. Epper (ed.), Focus on the budget: Rethinking current practice, state policy and college learning. Denver, CO: Education Commission of the States. 23-40. ERIC Document Reproduction Service. ED 375790.

Serban, A. (1998). Precursors of performance-funding. In J.C. Burke \& A.M. Serban (eds.), Performance funding for higher education: Fad or trend? New Directions for Institutional Research, 97, 15-24.

Shillington, W. (1998). Director, Business Planning and Evaluation, Advanced Education and Career Development. Correspondence. March 4.

Slaughter, S., \& Leslie, L.L. (1997). Academic capitalism: Politics, policies and the entrepreneurial university. Baltimore, ML: John Hopkins University Press.

Statistics Canada. (1999a). Population. CANSIM matrices 6367-6379. www.statcan.ca.

Statistics Canada. (1999b). Population of census metropolitan areas. CANSIM Matrix 6231. www.statcan.ca .

Treasury. (1998). 1998 budget estimates. Edmonton, AB: Author.

Treasury. (1999). 1999 budget estimates. Edmonton, AB: Author. 